\title{
Spiritism and Umbanda in Brazil: the Indian as a Figure of Worship and the Dilution of Identity Boundaries
}

\author{
Artur Cesar Isaia ${ }^{1}$ \\ ${ }^{1}$ La Salle University (Graduate Studies in Social Memory and Cultural Heritage); Federal University of Santa Catarina \\ (Graduate Studies in History); Researcher of the National Council for Scientific and Technological Development (CNPq). \\ Mail: UNILASALLE, Graduate Studies in Social Memory and Cultural Heritage. 2288, Victor Barreto Av., Canoas \\ Downtown, RS, Brazil
}

Correspondence: Artur Cesar Isaia, Victor Barreto Av., Canoas Downtown, RS, Brazil

Received: April 30, 2020

doi:10.11114/ijsss.v8i4.4865

Accepted: May 18, $2020 \quad$ Available online: May 20, 2020

URL: https://doi.org/10.11114/ijsss.v8i4.4865

\begin{abstract}
Brazilian Umbanda is a religion supported by trance and worship of ancestors. This religion is very close to Spirits', codified by Allan Kardec, the magical past and with the worship of ancestors of African origin. In contrast, the Spiritism of French origin, imported by Brazil in the second half of the 19th century, developed an identity close to literacy and science, sensitizing the sociocultural elite. With those characteristics, Spiritism tried to separate from Umbanda as Umbanda tried to get closer to Spiritism. This article discusses the figure of worship 'the Brazilian Indian' in Umbanda and his presence in Spiritism itself that contradict effort of his spokespersons to remove him from everything that could resemble Afro-Brazilian religions.
\end{abstract}

Keywords: Spiritism, Umbanda, Mediumistic Religions

\section{Introduction}

In the first half of the 20th century, Umbanda, a religion based on the mediumistic trance related to the French Spiritism of the 19th century, gained visibility in the Brazilian religious field. In this new religious modality, people started to worship ancestral spirits of the former owners of the Brazilian land, the Indians. These persons emerged in the Umbanda pantheon as entities called Caboclos. Interestingly, the Umbanda pantheon includes the worship of enslaved blacks, who came from Africa to work on export crops in Brazil in the colonial and imperial period. Even before the emergence of Umbanda, the 'trance with the presence' and worship of ancestors was very active in the religious universe of Africans of the Bantu ethnolinguistic group. T his group generally arose from sub-Saharan Africa.

For some researchers, the presence of Brazilian Indian worship in Umbanda was in agreement with re-elaborations of African memory in diaspora. With the weakening of ancestor worship, Africans and their descendants began to worship those considered as the first owners of Brazil, the Indians. In Santos (1995) and Slenes (2006), the Bantu had their original beliefs restructured in Brazil. Specifically, Santos studied the so-called "Caboclo Candomblé ", from Bahia. In this Candomble, the Orixas, the Brazilian Indian figure of worship begun to be included along with the ancient African deities. By studying the "Caboclo Candomblés" Carneiro (1991) illustrated the continuities with French Spiritism, imported to Brazil in the middle of the 19th century. Slenes (2006), in turn, studied the importance of belief in ancestral spirit possession by the Bantu in Brazil. Conversely, the worship of Caboclos was far from being monopolized by Umbanda in Brazil in the first half of the 20th century. In many cases, some spiritualist centers in Brazil started to invoke the spirit of Indians, opposing some doctrinal principles formally or informally promoted by the Brazilian Spiritualist Federation (FEB) ${ }^{\text {ii }}$ (Isaia \& Amorim, 2014). This is the case of the historical source analyzed in this article, which was obtained from a Spiritualist Center, located in the city of Rio de Janeiro and founded in 1934: Irradiação Magazine published by Cabana Espírita Antônio de Aquino.

\section{The Brazilian Indian as a Figure of Worship in Brazil}

There is empirical evidence of Indian worship in Brazil prior to the emergence of Umbanda in the religious field. For Edson Carneiro, survival of the Bantu religious universe in the so-called "Cabloclo Candomblés" dates back to the end of the 19th century (Carneiro, 1991). Additionally, in the Brazilian literature, both the poor and the elite constructed a character sought for magical-mythic help. This was the Cabocla do Castelo (Cabocla of the Castle), a character in the 
novel "Esaú e Jacó", by Machado de Assis, that was published early in the 20th century (Assis, 1976).

In a doctrinal work, Trindade (1991) mentions an interview held with an Umbanda pioneer, Antonio Leal de Souza dated 1952. In this interview, Leal de Souza referred to the worship of a Caboclo named Curuguçu, prior to the emergence of Umbanda in the Brazilian religious field. Silva (2007), another source of doctrinal nature, also mentions the presence of Caboclos predating the emergence of Umbanda. In the field of anthropology, Giumbelli (1997) and Silva (2002) recorded Alfred Alexander's observations from the end of the 19th century. They state that in the 19th century,spirits of Indians and Africans predominated spiritualist sessions in Brazil.

These authors emphasized that Indians and African spirits appeared in spiritualist seances as spirits that needed to be clarified, showing their transit. They then started to be worshipped as "bodies of light" in other ritual modalities such as the upcoming ritual modality Umbanda. In Umbanda, the identity of the Caboclo underwent the construction borrowed from the of Brazilian romantic literature, to be presented as a prominent, magnanimous and brave being. This is clearly exemplified in the identity of a spirit present in one of the myths that narrates the emergence or announcement of Umbanda in Brazil: the Caboclo of the Seven Crossroads. According to this narrative, this Caboclo announced or founded Umbanda in 1908, as a religion able to provide an open space for the worship of Indians and Africans, who were not tolerated as "spirits of light" in Brazilian Spiritism.

The Indian emerged in the Umbanda Pantheon as a re-elaboration of the historical figure of the Brazilian Indian. In this re-elaboration, there was an unquestionable presence of contents close to the romantic representation of the Brazilian Indian. In fact, Brazilian romantic literature, especially by José de Alencar and Gonçalves Dias, brought the Indian closer to the dominant values in society in the 19th century. This operation gave rise to a hybrid being, which preserved the external aspects of its culture, and internalized the symbolic and axiological codes inherent to Christianity and the aristocratic past of the Portuguese colonizer. A clear illustration of this is the character Peri, from "O Guarani" (Alencar, 1979). This character is able to deny his culture, his people, his mother and his gods to become a Christian and win the love of his beloved woman, the daughter of a Portuguese nobleman who lived in Brazil. Based on Carneiro (1991) and Romero's (1943) classic studies, Ortiz (1991) highlights the importance of Brazilian romanticism in elaborating a 'figure of worship' in the Indian among the Umbanda.

According to Ortiz, the Indian worshiped as Caboclo in Umbanda, emerges deprived of his own characteristics as someone wearing "white pants and shirts" (Ortiz, 1991, p. 72). In fact, a Brazilian modernist writer Oswald de Andrade, referred to the romantic Indian, eventually assumed by Umbanda, as a being "full of good Portuguese feelings" (Andrade, 1970, p. 16). Oswald de Andrade's irony can be extended to the Indian worshiped in Umbanda: the Caboclo. The Umbanda would worship an Indian that was divorced from his/her empirical reality. Umbanda represented this version of the Indian to combine some of its external signifiers (such as clothing, for example), with an axiological code very close to Christianity.

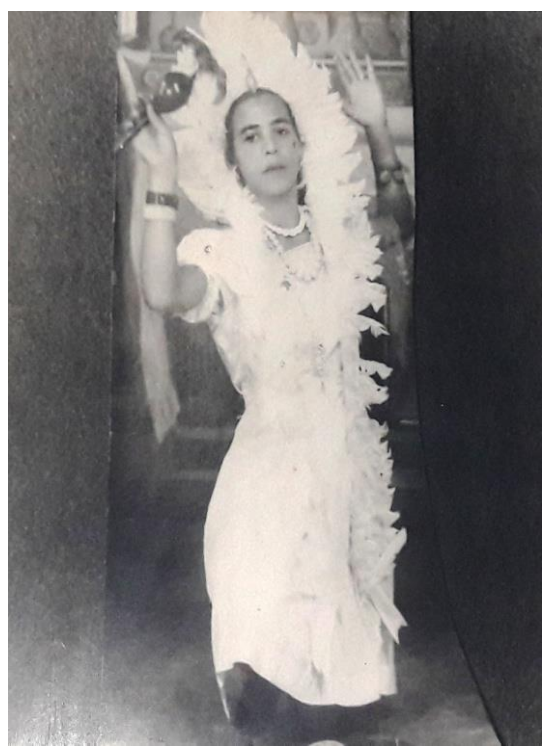

Figure 1. An "Indian" with her body completely covered in a theatrical performance promoted at Francisco de Assis Spiritualist Center, in Porto Alegre, RS, in the 1940s (Collection of Francisco de Assis Spiritualist Center) 
In the founding myth of the Caboclo of the Seven Crossroads, we found that these operations were able to articulate orality and writing and, popular and erudite culture like the cultural circularities studied by Bakhtin (1996). In this myth, similarities to French Spiritism are evident. In a society still strongly marked by aristocratic values such as the Brazilian society at the onset of the 20th century where both the indigenous and African past were belittled, the myth makes use of the concepts of reincarnation and evolution. These ideas, typical of the French Spiritism, arrived in Brazil in the middle of the 19th century and added a bookish European and erudite content to the past of the Caboclo of the Seven Crossroads.

In another incarnation in the past, the Caboclo of the Seven Crossroads would not be a "simple" Indian of the Brazilian jungles, but a priest extremely familiar with writing; the Jesuit of Lombard origin Gabriel de Malagrida. This Jesuit, a historical figure, had been a missionary in northern Brazil who was sentenced to death in Portugal after publishing a book that contradicted the Enlightenment of the Marquis of Pombal. In this book, he claimed that the earthquake in Lisbon in 1755 was a punishment from God. In "ponto cantado" (ritual song that identifies the spirit in Umbanda), the Seven Crossroads is represented as "an Indian, a fighting Caboclo, a Jesuit that Zambi iii had sent" (Ponto, 2019). These circularities appear in "ponto riscado" (a kind of shield that identifies the spirit in Umbanda), as well as in a picture painted by a medium in 1949. In both representations, there is a heart pierced by an arrow, which for some Umbanda followers refers to the Christian past of Seven Crossroads, and more precisely to the emblem of the Augustinian Order (Pai Juruá, 2011, p. 258).

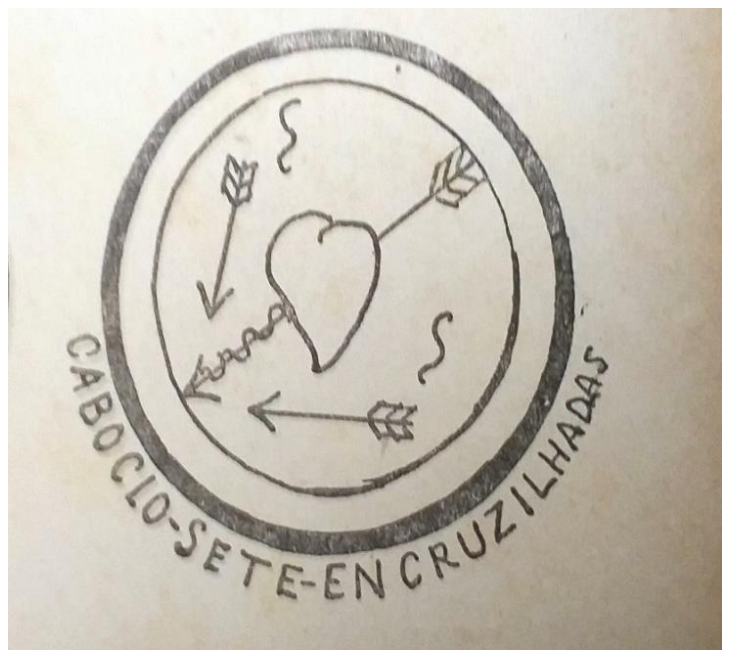

Figure 2. The Emblem or "Ponto Riscado" of Caboclo of Seven Crossroads (Silva, 1960, p. 76). The "Ponto Riscado" represents the spirit. It is crossed out with a chalk of limestone called "pemba"

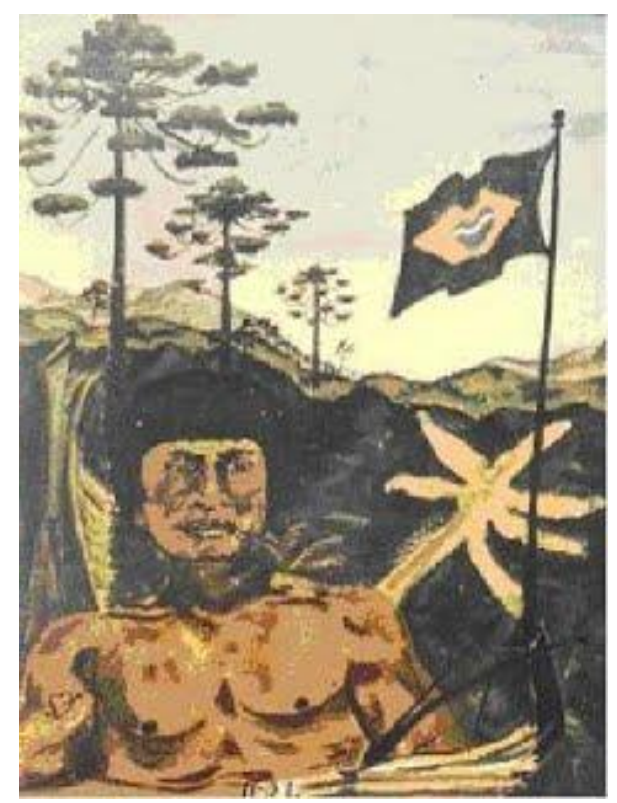

Figure 3. The same emblem ("Ponto Riscado") $s$ in Figure 2 is represented on the right arm of the Caboclo of Seven Crossroads, in a 1949 painting (Umbanda 100 Anos, p. 15) 


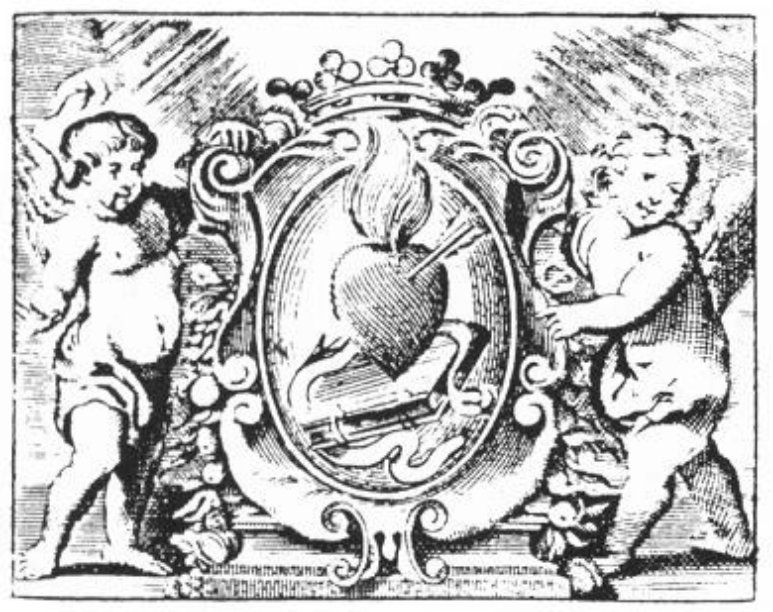

Figure 4. The same heart pierced by an arrow appears on the coat of arms of the Augustinian Order, which some Umbanda followers analogize with the symbol of the Caboclo of Seven Crossroads. Thus, Brazilian Umbanda built similarities, both with the 19th century French Spiritism and with the colonial religious past in Brazil based on Catholicism

(Associazione, 2019)

\section{The Brazilian Indian: Redefinitions Beyond Umbanda}

The Brazilian Indian with the attributes presented by Umbanda Caboclo, explicitly appears in the Cabana Antônio de Aquino in Rio de Janeiro amongst other places, a place that exists to this day in the district of Tijuca, in the Northern Zone of Rio de Janeiro. It is a spiritualist center independent from the Kardecist movement, that represents Indians similar to Umbanda Caboclos. Cabana Antônio de Aquino founded in 1934, originated from another spiritualist center in Rio de Janeiro called Casa de Lysis.

In the former center, the Indians were already present as mentor spirits with a representation very similar to that assumed by Umbanda and had been popularized by the marketing of religious images. In other words, the Indian was seen as a proud, strong, brave-being capable of lending these qualities to the charitable service of the inhabitants of the land.

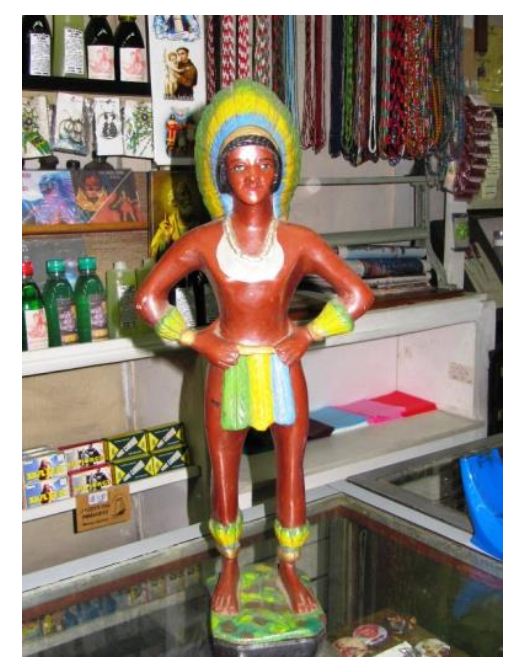

Figure 5. The popularized representation of Caboclo as an Indian, as it appears in the religious image market in Brazil (Author's photo)

In Casa de Lysis, the spiritualist center that preceded Cabana Antonio de Aquino, people made mediumistic painting among other activities. In the last category, we found a painting made by a female medium for use by the followers of Spiritism, sent from beyond the tomb that portrayed an Indian as a protector of the house, called Tupy. If this familiarity 
with the external representation of the Caboclo worshiped in Umbanda was not enough, Casa de Lysis and Cabana Antonio de Aquino also turned their backs on efforts by authorized spokespersons of Brazilian Spiritism in the Brazilian Spiritualist Federation who did not condone worship exteriorities such as paintings and images.

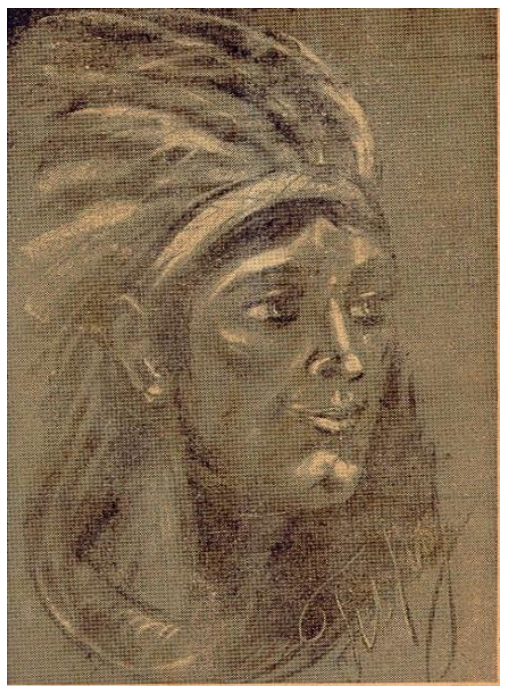

Figure 6. The representation of an Indian, protector of a Spiritualist Center, Casa de Lysis, portrayed by a medium in the 1930s. It is possible to see the proximity to the representation assumed by the Caboclos of the Brazilian Umbanda (Retrato, 1933, p. 101)

Despite Brazilian Spiritualist Federation's (FEB) doctrinal unification work, not all spiritualist centers are affiliate members. Therefore, spiritualist centers not affiliated to FEB portray a greater doctrinal ingenuity and a greater originality in the way they organize and serve the population. In a country where a mystical and spiritual idea of the notions of health and illness persist and formal public health appears theoretical to a large part of the population, spiritual places of service such as those connected to Spiritism and Umbanda are well accepted and legitimate. Consequently, spiritualist centers not affiliated to FEB provide the population with a wide range of spiritual "services" ranging from apometry to the so-called spiritual surgeries that contradict FEB doctrinal rigidity. In contrast, spiritualist centers not affiliated to FEB present a varied gallery of mentor spirits, many of whom such as the Brazilian Indians, align to the worship rendered to Caboclos in Umbanda. This also is the case of Cabana Antonio de Aquino, which is the focus of this article.

Cabana Antonio de Aquino preserved a good part of its memory collection in the magazine publication "Irradiação" which has been in circulation from 1938 to this day. The psychographics of the Indians published in this magazine, present symbolic operations that show a Christian monogamous Indian announcer of the political formulas, similar to the Brazilian state of the 1930s. For instance, there is an "autobiography" of an Indian named Canagé, who defines himself as "Brazilian", living on the banks of the Araguaia River centuries ago; i.e. long before the foundation of the national state in Brazil. This "autobiography" shows Canagé living living romantically for the rest of his life with an Indian, Cabocla Itaci:

Canagé also cheers with you. Canagé was Brazilian. He lived on the banks of Araguaia, a caboclo for centuries. Itaci was a Brazilian cabocla, mangaba $a^{\text {iv }}$ from your forests, smelling of wild anise, and that is why Canagé and Itaci cannot stop cheering with you today. Certainly, back then we were totally unaware of the magnitude of this land, but our souls were turned towards Tupan, our god and we praised him, and we paid tribute to the stars of your sky and our sky. And when the moon floated in the sky, she was our goddess, the goddess of our very Brazilian love, our passionate love ... (Brasileiros, 1939, p. 11-12).

The psychography above makes sense when we contextualize the moment it arose. In the second half of the 1930s, Brazil experienced dictatorship of the New State (1937-1945) under Getúlio Vargas. This was a political experience based on a fierce nationalism and an organic anti-parliamentary model, in which there was a redefinition of the liberal concept of citizenship. This concept was replaced by a citizen who defined himself, as a producer, above all. In this political experience, the free man, who associated with institutions able to represent him in the public sector, such as political parties (DUVERGER, 1980), was replaced by a citizen linked to institutions considered "apolitical", which organized and represented him as a producer in a corporate way. In this context, the political discourse conveyed by the state praised Brazilian work and workers, as a paternal and protective state that granted labor rights which were absent in the previous republican state. In the "Irradiação" magazine we find in a psychography in which Canagé Indian praised the excellence 
of "labor laws" who did not condone worship exteriorities such as paintings and using the vocative that was so popularized by Vargas at beginning of his speeches to the working mass: Workers of Brazil.

Spiritualist Brazilians, workers of Brazil, while you are perfecting your souls daily, you are certainly working closely for the magnitude of this people, for the brightness of this land, because the example that remains is that of people who know how to comply with their obligations as human beings, who have a clear conscience, who value their homeland above all. The example is certainly long lasting. Happy is the man who can regretfully say when closing his eyes to the world: I fulfilled my fatherly duty. I was a good role model. At least, I tried to fulfill my duty as a citizen, because I worked honestly. I fulfilled my duty to God because I always tried to be faithful to him. But, my friends, it is necessary and appropriate to remind you of the laws of work: working for the country, for the family, fulfilling the teachings of Christ of God and, therefore, before God (Brasileiros, 1939, p. 11-12, emphasis added).

The publication is an efficient demonstration of the relations developed between Getúlio Vargas' dictatorship and the so-called "mediumistic religions" such as Spiritism and Umbanda in Brazil in the 1930s (Isaia, 2019). Even more explicit is a poem published on November 19, 1940 about building a model of Indian linked to national guidelines. It is important to note that this date corresponds to the National Flag Day in Brazil. The nationalism and the political centralization operated by Vargas in the dictatorship of the New State ended with the flags of the states, which were then banned and replaced by the only national flag when the federation was replaced by state unitarianism. In this context, the Indian Canagé praised the national flag, in complete agreement with the dictatorship's political guidelines:

There is the green of hope of the forest. And there is also the waves of the sea. The white cloud lends its color. And the sun gives it all its flash. There is blue and constellation, The language of white light, shiny! Order and Progress - this is the definition: - Souls, unite for the same ideal! Oh river, Oh land, Oh sea!... Fruitful fields... Oh breeze that walks through other worlds. Say the sky here is always indigo. And that with glories this poem ends. The beautiful pavilion of our land. The magnificent flag of Brazil! (Saudação, 1940, p. 9).

The Indian Canagé, by showing he was perfectly inserted in the supportive discourse of the New State, lending his condition of first inhabitant of Brazil to the work of ideological socialization of Vargas dictatorship, once again confirmed Oswald de Andrade's irony.

\section{Conclusion}

The study of the so-called mediumistic religions in Brazil shows the relevant position of the Indian in the worship universe of both Umbanda and religious realities such as Spiritism. In the case of Umbanda, the figure of the Indian as part of its pantheon is explicit. The Indian celebrated by Umbanda, emerges with attributes similar to the romantic indigenous representation of the 19th century Brazilian literature. In this sense, he portrays clear circularities with the dominant religion Christianity.

By worshiping the Indian, Umbanda historically created an entity that despite resembling the first owner of the land, also boasted qualities similar to the Christian standards and the values that supported the social order. These values were clearly established in the first half of the 20th century when Umbanda emerged as a religious option in Brazil. Spiritism, in turn, accompanied the familiarity with which the Indian appeared as a worship figure, able to establish in the source of Umbanda. As mentioned in the previous pages, the Spiritism familiar with the worship figure of the Indian is the one distanced from authorized spokespersons of Spiritism, the Brazilian Spiritualist Federation.

Among some types of Spiritism and Umbanda, there will be evident exchanges in Brazil. On the one hand, in some spiritualist centers in Brazil you will encounter a worship figure very familiar to the imaginations of a significant proportion of the Brazilian population, clearly present in the Umbanda pantheon, the Indians. On the other hand, some manifestations of Umbanda absorbed from Spiritism some distinguishing characteristics such as literacy and a discourse with pretensions to scientificity. These circularities will be visible, above all, in the first half of the 20th century, when an "Umbanda Spiritism" develops as Umbanda's legitimate strategy, seeking to approach a cultural partner with a considerable symbolic accumulation such as Spiritism. In both cases, the presence of the Indian indicates a previous familiarity with a signifier equipped with considerable symbolic accumulation.

A debtor to the spiritualist exegesis of the end of the 19th century, the Indian will emerge, in all cases, as an entity able to celebrate a harmonious and conciliatory representation of Brazilian nationality. Conversly, in Brazilian Spiritism, the presence of the Caboclo in the spiritualist sources studied here shows that the Brazilian Spiritualist Federation, which placed itself as an authorized spokesperson, was unable to monopolize an identity project able to completely separate him both from the Afro-Brazilian religions and from the symbolic reality and memory of a good part of the Brazilian population. 


\section{References}

ALENCAR, J. D. (1979). O Guarani. Rio de Janeiro: Otto Pierre Editores.

ANDRADE, O. D. (1970). Obras completas de Oswald de Andrade. Rio de Janeiro: Civilização Brasileira, 1970.

ANJOS, J. C. D. (2008). A filosofia política da religiosidade afro-brasileira como patrimônio cultural africano. Debates do NER, 7(13), 77-96. https://doi.org/10.22456/1982-8136.5248

ASSIS, M. D. Esaú e Jacó. (1976). Rio de Janeiro: Francisco Alves, 1976.

ASSOCIAZIONE, S. S. A. (2019). Retrieved from http://www.cassiciaco.it/navigazione/iconografia/iconografia\%20generale/stemma/anversa_1689.html

BAKHTIN, M. (1996). A cultura popular na Idade Média e no Renascimento: o contexto de François Rabelais. São Paulo: Hucitec.

BRASILEIROS, AMAI VOSSA PÁTRIA E CUMPRI VOSSO DEVER. (1939). Irradiação: Revista da Cabana de Antonio de Aquino. Rio de Janeiro, 2(1), 11-12.

CARNEIRO, E. As Religiões Negras. Negros Bantos. (1991). Rio de Janeiro: Civilização Brasileira.

DAIBERT, R. (2015). A religião dos bantos: novas leituras sobre o calundu no Brasil colonial. Estudos Históricos, 28(55), 7-25. https://doi.org/10.1590/S0103-21862015000100002

DUTRA, E. Dicionário de Umbanda. (1957). São Paulo: Bentivegna.

DUVERGER, M. (1980). Os partidos políticos. Rio de Janeiro: Zahar.

GIUMBELLI, E. (1997). O cuidado dos mortos: uma história de condenação e legitimação do Espiritismo. Rio de Janeiro: Arquivo Nacional.

Religion and Dictatorship in Brazil: the Case of Umbanda in Getúlio Vargas's New State (1937-1945). (2019). Review of History and Political Science, 7(2), 26-41. https://doi.org/10.15640/rhps.v7n2a4

ISAIA, A. C., \& AMORIM, P. P. (2014). O Almenara: as religiões afro-brasileiras em um periódico de oposição à Federação Espírita Brasileira (meados do século XX). Mneme. Revista de Humanidades, 15(34), 151-166.

ORTIZ, R. A morte branca do feiticeiro negro. Umbanda e Sociedade Brasileira. (1991).São Paulo: Brasiliense.

PAI JURUÁ. O Ritual do Rosário das Santas Almas Benditas. (2011). São Caetano do Sul: s. ed.

PONTO, D. CABOCLO DAS SETE ENCRUZILHADAS. (2019). Pontos Cantados. Retrieved from https://www.ceseteflechas.com.br/ponto/ponto-de-caboclo-das-sete-encruzilhadas

RETRATO DE TUPI. (1932). Novo Horizonte. Rio de Janeiro, 1(1), 30.

ROMERO, S. História da Literatura Brasileira. (1943) Rio de Janeiro: José Olyimpio.

SANTOS, J. T. (1995). Os caboclos nos candomblés da Bahia. Salvador: Sarah Letras.

SAUDAÇÃO À PÁTRIA. (1940). Irradiação: Revista da Cabana de Antonio de Aquino, 3(1), 9.

SILVA, Benedito da. Ritual da Umbanda. (1960). Rio de Janeiro: Organização Simões Editora.

SILVA, V. G. (2002). Caminhos da alma. Memória afro-brasileira. São Paulo: Selo Negro.

SILVA, W. W. (2007). Umbanda e o poder da mediunidade. São Paulo: Ícone.

SLENES, R. (2006). A árvore de Nsanda: cultos kongo de aflição e identidade escrava no sudeste brasileiro (século XIX). (2006). In: LIBB, Douglas Cole; FURTADO, Júnia Ferreira (orgs.). Trabalho livre, trabalho escravo: Brasil e Europa séculos XVII e XIX, São Paulo: Annablume.

TRINDADE, D. F. (1991). Umbanda e sua história. São Paulo: Ícone.

. A construção histórica da literatura umbandista. (2010) Limeira: Editora do Conhecimento.

UMBANDA 100 ANOS. (2008). Revista Espiritual de Umbanda, 5(20), 12-15.

\footnotetext{
${ }^{\text {i }}$ For Prandi (2005, p. 304), Candomble simultaneously designates the religion of the Orixás, the African gods and the place of worship. The basic difference between Candomblé and Umbanda is that in the latter, instead of Orixás, the spirits considered ancestral or connected to the Brazilian imaginary "descend on" earth. However, nowadays, Umbanda worship started to refer simultaneously to Orixás and the Spirits (similar to the Caboclo Candomblés from Bahia).
} 
${ }^{\text {ii }}$ FEB was founded in 1884 and until this day it has worked for the coordination and doctrinal centralization of Spiritism in Brazil.

iii For the peoples of the Bantu ethnolinguistic group, there was a single, supreme God, creator of everything, called Zambi (Daibert, 2015; Dutra, 1957).

${ }^{\text {iv }}$ Mangaba is the fruit of the mangabeira tree. It is edible and used to make juice, ice cream, candy and drinks.

\section{Copyrights}

Copyright for this article is retained by the author(s), with first publication rights granted to the journal.

This is an open-access article distributed under the terms and conditions of the Creative Commons Attribution license which permits unrestricted use, distribution, and reproduction in any medium, provided the original work is properly cited. 